\title{
Phylogeny and Pathogenicity of Phytophthora Species Associated with Artichoke Crown and Root Rot and Description of Phytophthora marrasii sp. nov. ${ }^{\dagger}$
}

\author{
Carlo Bregant ${ }^{1}$, Giovanni Rossetto ${ }^{1}\left(\mathbb{D}\right.$, Antonio Deidda ${ }^{2}\left({ }^{1}\right.$, Lucia Maddau $^{2}$, Antonio Franceschini ${ }^{2}$, \\ Giorgio Ionta ${ }^{3}$, Alessandro Raiola ${ }^{1}\left(\mathbb{D}\right.$, Lucio Montecchio ${ }^{1}$ and Benedetto T. Linaldeddu ${ }^{1, *}$ (i)
}

check for updates

Citation: Bregant, C.; Rossetto, G.; Deidda, A.; Maddau, L.; Franceschini, A.; Ionta, G.; Raiola, A.; Montecchio, L.; Linaldeddu, B.T. Phylogeny and Pathogenicity of Phytophthora Species Associated with Artichoke Crown and Root Rot and Description of Phytophthora marrasii sp. nov. Agriculture 2021, 11, 873. https://doi.org/10.3390/ agriculture11090873

Academic Editors: Beatrice Berger, Matthias Becker, Anna Andolfi and Sabrina Palmano

Received: 20 July 2021

Accepted: 10 September 2021

Published: 12 September 2021

Publisher's Note: MDPI stays neutral with regard to jurisdictional claims in published maps and institutional affiliations.

Copyright: (c) 2021 by the authors. Licensee MDPI, Basel, Switzerland. This article is an open access article distributed under the terms and conditions of the Creative Commons Attribution (CC BY) license (https:/ / creativecommons.org/licenses/by/ $4.0 /)$
1 Dipartimento Territorio e Sistemi Agro-Forestali, Università degli Studi di Padova, Viale dell'Università 16, 35020 Legnaro, Italy; carlo.bregant@studenti.unipd.it (C.B.); giovanni.rossetto.4@studenti.unipd.it (G.R.); alessandro.raiola@unipd.it (A.R.); montecchio@unipd.it (L.M.)

2 Dipartimento di Agraria, Università degli Studi di Sassari, Viale Italia 39, 07100 Sassari, Italy; adeidda@uniss.it (A.D.); lmaddau@uniss.it (L.M.); frafenudi@gmail.com (A.F.)

3 Via Giovanni Acuto 13, 09134 Cagliari, Italy; gi.ionta@tiscali.it

* Correspondence: benedetto.linaldeddu@unipd.it

+ This paper is dedicated to the memory of Francesco Marras, who passed away on 5 January 2021. The scientific interests of F.M. embraced various sectors of plant pathology, including the management globe artichoke diseases.

Abstract: Field surveys conducted on nine farms over a 2-year period showed the widespread presence of Phytophthora-related diseases on globe artichoke plants in the main growing area in Sardinia (Italy). Characteristic symptoms included wilting and necrosis of the outermost leaves and dark brown discoloration of stem tissues, as well as root rot. A total of 18 Phytophthora colonies belonging to three species were isolated and characterized. Based on morphological features and ITS sequence data, Phytophthora isolates were identified as P. crassamura (eight isolates) and P. cactorum (four isolates). Six isolates could not be assigned to any formally described species of Phytophthora and are therefore described here as Phytophthora marrasii sp. nov. The ITS phylogeny places $P$. marrasii in a terminal clade basal to the sister taxa ( $P$. foliorum, $P$. hibernalis, $P$. lateralis, and $P$. ramorum) of the clade 8c. In particular, P. marrasii is phylogenetically related to P. foliorum, a species from which it differs in 62 nucleotides in the ITS region. At the same time, it can easily be distinguished morphologically from $P$. foliorum mainly because of the low minimum temperature for growth, the bigger and persistent non-papillate sporangia, and smaller oogonia. Pathogenicity tests confirmed that all three Phytophthora species are pathogenic on globe artichokes, which represent a new host for these pathogens.

Keywords: micropropagation; varieties; emerging pathogens; taxonomy; ITS clade8

\section{Introduction}

The globe artichoke (Cynara cardunculus L. subsp. scolymus (L.) Fiori) is a perennial edible plant well adapted to the xerothermic conditions of the Mediterranean region, where it is traditionally cultivated as an open-field crop [1,2]. The main product consists of the immature inflorescence (capitulum), which can be used as an ingredient in several traditional dishes [3,4]. Globe artichoke is also a multipurpose crop that can be utilized for a series of secondary products, such as inulin, biopharmaceuticals, oil, and biomass for energy [5-8]. Globe artichoke cultivation is based mainly on clones vegetatively propagated via "stumps" (basal stem pieces with attached root sections) or underground dormant buds "ovoli" $[9,10]$. In both traditional and emerging globe artichoke-producing countries, a number of different varieties are cultivated, but 12 are considered to be of commercial relevance [11-13]. The varieties can be distinguished chiefly on the basis of capitulum morphology, colour, and harvest time [3,13]. 
Italy is the leading artichoke-producing country, with a total crop area of 40,500 hectares and a total production of 388,000 tons [2]. Commercial plantings are mainly concentrated in southern regions and on the two main islands, Sicily and Sardinia [1,2]. In particular, Sardinia encompasses $21 \%$ of the national cultivated area with a production of 50,000 tons. The cultivar "Spinoso sardo" is the main cultivated variety as it is appreciated by local, national, and international markets [14,15]. Recently, some cultivars with thornless capitula, such as "Romanesco" and "Tema", have been growing in importance thanks to the use of micropropagated plants $[4,16,17]$. In Sardinia, cropping is biannual or annual, depending on water availability and the incidence and impact of diseases $[18,19]$.

Despite the economic importance of globe artichoke worldwide, very few studies have addressed the diseases affecting this open-field crop. Among the main diseases that affect the normal development of artichoke, Verticillium wilt, caused by the fungus Verticillium dahliae, is becoming a threat to artichoke production and its industry [20-22]. Other fungal pathogens associated with artichoke crops worldwide are Athelia rolfsii (syn. Sclerotium rolfsii), Rhizoctonia solani, two crown rot agents, and Botrytis cinerea, the causal agent of the disease known as gray mould rot [23-27]. In Sardinia, A. rolfsii and R. solani are considered the main yield-limiting factors due to their virulence and ability to persist in the soil through long-living sclerotial structures $[23,24,28]$. To limit the impact of these soil-borne pathogens, the artichoke crop is rotated with other crops, such as alfalfa, wheat, or tomato $[29,30]$. Besides fungal diseases, several bacteria and viruses can decrease both the productivity and quality of the crop [31-33].

Since 2018, a severe globe artichoke disease responsible for heavy yield losses has been observed in the major artichoke-producing area in southern Sardinia. Since the symptoms were indicative of Phytophthora root rot, but no Phytophthora species were reported associated with globe artichoke in the literature, a survey was conducted to establish the causal agents.

\section{Materials and Methods}

\subsection{Sites, Sampling Procedure, and Phytophthora Isolations}

An extensive field survey was performed from 2020 to 2021 in one of the most important Sardinian globe artichoke production districts in southern Sardinia (locality Samassi) (Table 1). Nine farms were surveyed for disease incidence, and 19 symptomatic plants showing stunted growth, chlorosis of lower leaves, and crown and root rot were randomly collected for diagnostic analyses (Table 1). From the same plants, rhizosphere samples (about $300 \mathrm{~g}$ ) were collected for Phytophthora isolation. Plant and rhizosphere samples were sealed in plastic bags, labelled, and used for Phytophthora isolations within $48 \mathrm{~h}$. In the laboratory, artichoke samples (rhizosphere soil and necrotic roots) were placed in plastic boxes with $2 \mathrm{~L}$ of distilled water. After $24 \mathrm{~h}$ at $20^{\circ} \mathrm{C}$, the water surface was cleaned and 5-7 young Quercus suber leaves taken from 5-months-old seedlings were placed on the surface as bait [34]. Boxes were kept at $20^{\circ} \mathrm{C}$ under natural daylight for 7 days. Leaves showing dark-brown spots were checked for occurrence of sporangia, cut into small pieces $\left(5 \mathrm{~mm}^{2}\right)$, and placed on Petri dishes containing potato dextrose agar (PDA $39 \mathrm{~g} / \mathrm{L}$, Oxoid Ltd., Basingstoke, UK), supplemented with $100 \mathrm{~mL} / \mathrm{L}$ of carrot juice, $0.013 \mathrm{~g} / \mathrm{L}$ of pimaricin, and $0.05 \mathrm{~g} / \mathrm{L}$ of hymexazol (PDA+) [35]. Hyphal tips from Phytophthora-like colonies were taken with a sterile needle under microscope and then sub-cultured on PDA and carrot agar (CA) [36].

Furthermore, Phytophthora isolations were performed from capitula, basal leaves, and crown and root samples with dark-brown lesions. After disinfecting the external surface with $70 \%$ ethanol, small fragments $\left(5 \mathrm{~mm}^{2}\right)$ were aseptically cut from the margin of necrotic lesions with a sterile scalpel and placed onto $90 \mathrm{~mm}$ Petri dishes containing PDA+. The plates were incubated in the dark at $18{ }^{\circ} \mathrm{C}$ and examined every $6-12 \mathrm{~h}$ for Phytophthora-like colonies. Pure colonies were obtained as described above. 
Table 1. Details of surveyed farms and number of plants collected for Phytophthora isolation.

\begin{tabular}{cccccc}
\hline Farm & Cultivar & Origin of Plants & Planting Period & Sampling Period & Number of Samples \\
\hline F1 & Romanesco & Micropropagated & July 2019 & February 2020 & 3 \\
F2 & Romanesco & Micropropagated & July 2019 & February 2020 & 3 \\
F3 & Romanesco & Micropropagated & July 2019 & February 2020 & 1 \\
F4 & Romanesco & Micropropagated & July 2019 & July 2020 & 1 \\
F5 & Romanesco & Micropropagated & July 2019 & July 2020 & 1 \\
F6 & Romanesco & Micropropagated & July 2019 & July 2020 & 1 \\
F7 & Romanesco & Micropropagated & July 2020 & February 2021 & 3 \\
F8 & Romanesco & Micropropagated & July 2020 & February 2021 & 3 \\
F9 & Romanesco & Micropropagated & July 2020 & February 2021 & 3 \\
\hline
\end{tabular}

\subsection{Morphological Identification and Characterization of Isolates}

All Phytophthora isolates obtained in pure culture were preliminarily grouped in morphotypes and identified by morphological analysis (colony appearance, shape, and size of sporangia, as well as gametangial features). Colony morphology was determined on 7-day-old cultures incubated at $25{ }^{\circ} \mathrm{C}$ in the dark on CA, PDA, and malt extract agar (MEA, $20 \mathrm{~g} / \mathrm{L}$, Oxoid Ltd., Basingstoke, UK). The production of chlamydospores, hyphal swellings, and sporangia was evaluated on CA. To enhance sporangia production, mycelial agar plugs (5 $\mathrm{mm}$ diameter) taken from the margin of actively growing colonies (4-day-old) on CA were placed with mycelial side up in Petri dishes containing unsterile pond water and 3 Quercus suber roots $1 \mathrm{~cm}$ long [36]. Petri dishes were kept at $12-18{ }^{\circ} \mathrm{C}$ in the dark, and sporangia production was assessed every $12 \mathrm{~h}$ for 4 days. Gametangial production in single culture was examined on CA Petri dishes $(90 \mathrm{~mm})$ incubated for 21 days in the dark at $18{ }^{\circ} \mathrm{C}$. The mating behaviour was also tested in dual culture on CA, pairing two isolates of the same species together or with a heterothallic isolate of the known mating type (A1 and A2) of Phytophthora cambivora [CB67 (A1); CB1 (A2)], P. cinnamomi [CBS 144.22 (A2)], P. citrophthora [CB314 (A1)], and P. nicotianae [CB315 (A1); CB316 (A2)], as described by Brasier [37]. In addition, gametangial induction was studied, placing a $5 \mathrm{~mm}$ diameter plug from the edge of an actively growing colony on CA incubated at $18^{\circ} \mathrm{C}$ in the dark for 5 days in Petri dishes with $5 \mathrm{~mL}$ of unsterile pond water.

The effect of temperature on growth was tested in vitro on $90 \mathrm{~mm}$ CA Petri dishes incubated at $2,5,10,15,19,20,23,25,27,28$, and $30^{\circ} \mathrm{C}\left( \pm 0.5^{\circ} \mathrm{C}\right)$ in the dark. In more detail, agar plugs ( $5 \mathrm{~mm}$ diameter) taken from 4-day-old colonies, growing at $20 \pm 0.5^{\circ} \mathrm{C}$ on $\mathrm{CA}$, were placed top side down in the centre of new media plates, with five replicates per isolate. After $96 \mathrm{~h}$, the diameter of resulting colonies was measured twice at right angles on each plate and then averaged after subtraction of the original plug diameter.

Measurements and photos of the main morphological structures (chlamydospores, hyphal swellings, sporangia, oogonia, and antheridia) were taken at $400 \times$ and $600 \times$ magnification and recorded using the software Motic Images Plus 3.0, paired with a Moticam $10+$ camera connected to a Motic BA410E microscope. Dimensions of the morphological structures are presented as mean values \pm standard deviation of 50 measurements.

Representative isolates of each species were stored on PDA and CA slants under oil in the culture collection of the Dipartimento Territorio e Sistemi Agro-Forestali, Università degli Studi di Padova. Ex-type culture of the new species was deposited at the Westerdijk Fungal Biodiversity Institute, Utrecht, The Netherlands, and nomenclatural data in $\mathrm{My}-$ coBank (www.MycoBank.org, accessed on 16 July 2021). The holotype was lodged with the herbarium of Westerdijk Fungal Biodiversity Institute as a dried culture on CA.

\subsection{DNA Extraction, Polymerase Chain Reaction (PCR) Amplification, and Sequencing}

The identities of all isolates were confirmed by DNA sequence analysis. Genomic DNA was extracted from mycelium of 4-day-old cultures, as described by Linaldeddu et al. [38]. The entire internal transcribed spacer (ITS) region of the ribosomal DNA, including the $5.8 \mathrm{~S}$ rRNA gene, was amplified and sequenced using primers ITS1 and ITS4 [39]. ITS sequences 
were used to confirm the identification at species level. For the isolates of the new species, another two DNA regions, namely $\beta$-tubulin (Btub) and cytochrome c oxidase subunit I (cox 1$)$, were amplified and sequenced using the primer-pairs TUBUF2/TUBUR1 and FM84/FM83 [40,41]. PCR amplification conditions and reaction mixtures were performed, as described by Bregant et al. [34].

PCR products were purified using a EUROGOLD gel extraction kit, according to the manufacturer's instructions (EuroClone S.p.A., Pero, Italy). Both strands were sequenced by BMR Genomics DNA sequencing service (www.bmr-genomics.it (accessed on 16 July 2021)). Sequences were edited with FinchTV v1.4.0 (http:/ / www.geospiza.com/finchtv (accessed on 16 July 2021)) and compared with sequences of ex-type culture deposited in GenBank. New sequences were deposited in GenBank (Tables 2 and 3).

Table 2. Phytophthora isolates belonging to clade 8 included in the Maximum Likelihood (ML) analyses. Ex-type cultures are given in bold typeface, and sequences obtained in this study are indicated in italics.

\begin{tabular}{|c|c|c|c|c|c|}
\hline \multirow{2}{*}{ Species } & \multirow{2}{*}{ Code } & \multirow{2}{*}{ Host } & \multicolumn{2}{|c|}{ GenBank Accession Number } & \multirow[b]{2}{*}{$\operatorname{cox} 1$} \\
\hline & & & ITS & Btub & \\
\hline P. austrocedrae & CBS 122.911 & Austrocedrus chilensis & MG783380 & - & - \\
\hline P. austrocedrae & AG318 & A. chilensis & KU953997 & - & - \\
\hline P. brassicae & CBS 179.87 & Brassica oleracea & NR147859 & - & - \\
\hline P. brassicae & CBS 112277 & B. oleracea & KC478766 & - & - \\
\hline P. cichorii & CBS 115029 & Cychorium intybus & KC478773 & - & - \\
\hline P. cichorii & CBS 115030 & C. intybus & KC478775 & - & - \\
\hline P. cryptogea & CBS 113.19 & $\mathrm{n} / \mathrm{d}$ & MG865483 & - & - \\
\hline P. cryptogea & SCRP 205 & Solanum tuberosum & AY659423 & - & - \\
\hline P. dauci & CBS 127102 & Daucus carota & MH620160 & - & - \\
\hline P. dauci & CBS 114039 & D. carota & KC478762 & - & - \\
\hline P. drechsleri & CBS 292.35 & Beta vulgaris & MG865484 & - & - \\
\hline P. drechsleri & LEV 6732 & Petunia $\times$ hybrida & MH025882 & - & - \\
\hline P. erythroseptica & CBS 129.23 & Solanum tuberosum & MG865486 & - & - \\
\hline P. erythroseptica & MUC 837 & S. tuberosum & MG196242 & - & - \\
\hline P. foliorum & CBS 121655 & Rhododendron sp. & MG865492 & MH493937 & MH136889 \\
\hline P. foliorum & FC160118 & R. ponticon & KX364273 & - & - \\
\hline P. foliorum & P10969 & Rhododendron sp. & HQ261561 & - & HQ261308 \\
\hline P. hibernalis & CBS 114104 & Citrus sp. & MG865506 & MH493948 & MH136900 \\
\hline P. hibernalis & CBS 270.31 & Citrus sinensis & KT183039 & KX252120 & - \\
\hline P. hibernalis & $116-0007$ & $\mathrm{n} / \mathrm{d}$ & MF441623 & - & MF441668 \\
\hline P. lactucae & P19872 & Lactuca sativa & MH620161 & - & - \\
\hline P. lactucae & BPIC1988 & L. sativa & KC478770 & - & - \\
\hline P. lateralis & CBS 168.42 & Chamaecyparis sp. & MG865522 & MH493964 & MH136917 \\
\hline P. lateralis & P2522 & C. lawsoniana & JQ837654 & JQ837665 & JQ837677 \\
\hline P. marrasii & CB150 & Cynara scolymus & MZ569854 & MZ603724 & OK054535 \\
\hline P. marrasii & CB149 & C. scolymus & MZ569855 & $M Z 603723$ & OK054536 \\
\hline P. medicaginis & CBS 119902 & Medicago sativa & MG865532 & - & - \\
\hline P. medicaginis & $23 \mathrm{~A} 4$ & M. sativa & KF358223 & - & - \\
\hline P. obscura & CBS 129273 & Soil & MG865554 & - & - \\
\hline P. obscura & 6.18 & Acer pseudoplatanus & MN228692 & - & - \\
\hline P. porri & CBS116662 & Allium porrum & KC478749 & - & - \\
\hline P. porri & CBS127099 & A. porrum & KC478750 & - & - \\
\hline P. primulae & CBS 114346 & Primula polyantha & MG865571 & - & - \\
\hline P. primulae & CBS110162 & Primula sp. & HQ643324 & - & - \\
\hline P. pseudocryptogea & CBS 139749 & Isopogon buxifolius & KP288376 & - & - \\
\hline P. pseudocryptogea & SUC 633 & Solanum melongena & KP099906 & - & - \\
\hline P. ramorum & CBS 101553 & Rhododendron sp. & MG865581 & LC595884 & MH136973 \\
\hline P. ramorum & P2058 & Rhododendron sp. & MW300319 & MW323707 & MW323671 \\
\hline P. sansomeana & CBS 117693 & Glycine $\max$ & MG865585 & - & - \\
\hline P. sansomeana & KSSO 6-47 & G. $\max$ & KU209481 & - & - \\
\hline P. syringae & CBS 110161 & Syringa vulgaris & MG865590 & - & - \\
\hline P. syringae & CBS 364.52 & Prunus armeniaca & HQ643358 & - & - \\
\hline P. trifolii & CBS 117687 & Trifolium sp. & MG865594 & - & - \\
\hline P. trifolii & P1462 & Trifolium sp. & HQ261719 & - & - \\
\hline
\end{tabular}


Table 3. Disease severity detected on globe artichoke plants inoculated with the representative Phytophthora isolates obtained in this study.

\begin{tabular}{ccccc}
\hline Scheme & Isolate Code & $\begin{array}{c}\text { GenBank Accession } \\
\text { Number }\end{array}$ & $\begin{array}{c}\text { Disease } \\
\text { Severity }\end{array}$ & $\begin{array}{c}\text { Re-Isolation } \\
\text { Frequency (\%) }\end{array}$ \\
\hline P. cactorum & CB266 & MZ569852 & $2.9 \pm 0.3$ & $100 \%$ \\
P. crassamura & CB267 & MZ569853 & $2.5 \pm 0.5$ & $100 \%$ \\
P. marrasii & CB150 & MZ569854 & $1.9 \pm 0.6$ & $100 \%$ \\
Control & - & - & 1 (asymptomatic) & - \\
\hline${ }^{*}$ Data are presented as mean values \pm standard deviation. & &
\end{tabular}

\subsection{Phylogenetic Analysis}

Single and multi-gene phylogeny based on concatenated ITS/Btub and ITS/cox1 sequences was used to reconstruct evolutionary relationships among two Phytophthora isolates obtained in this study and the 20 formally described Phytophthora species in the clade 8 , including ex-type culture (Table 2).

Sequences were aligned with ClustalX v. 1.83 [42], using the parameters reported by Bregant et al. [34]. Alignments were checked and edited with BioEdit Alignment Editor v. 7.2.5 [43].

Maximum likelihood (ML) analyses were done with MEGA-X 10.1.8 [44]. MEGA$X$ was also used to determine the best fitting DNA evolution model to be used for ML analysis. All gaps were included in the analyses. ML analysis was performed with a neighbour-joining (NJ) starting tree generated by the software. A bootstrap analysis (1000 replicates) was used to estimate the robustness of nodes. Alignments and trees are available in TreeBase (studies 28540, 28541, and 28728).

\subsection{Pathogenicity Tests}

Pathogenicity of the Phytophthora species obtained in this study was evaluated on 1-month-old globe artichoke plants grown in plastic pots $(0.3 \mathrm{~L}$ volume). Ten seedlings (cv. Romanesco) were inoculated for each Phytophthora species using the isolates CB266, CB267, and CB150. The same number of globe artichoke seedlings were used as the control.

Inoculation was performed on the upper surface of the leaf. The inoculated point was initially surface-disinfected with 70\% ethanol and an agar-mycelium plug ( $3 \mathrm{~mm}$ diameter), taken from the edge of an actively growing colony on PDA, applied on the leaf surface with the mycelial side down. Four leaves were inoculated for each plant. The inoculation point was covered with cotton wool soaked in sterile water. Controls were inoculated with a sterile PDA plug. All inoculated seedlings were kept in a climatic chamber at $24{ }^{\circ} \mathrm{C}$ and watered daily. After 5 days, all plants were checked for the presence of disease symptoms and the disease severity was estimated on the basis of the proportion of wilted foliage following the scale: 1 = no disease; 2 moderate $=$ partial wilt of leaves; 3 severe $=$ wilted leaves, death of the plant.

Re-isolation was performed from necrotic leaves. Small fragments were taken randomly around the leaves and placed onto PDA+. Growing colonies were sub-cultured onto $\mathrm{CA}$ and PDA, incubated in the dark at $18{ }^{\circ} \mathrm{C}$ and identified by analysis of the ITS region to confirm Koch's postulates.

\section{Results}

\subsection{Symptomatology and Aetiology}

Field surveys conducted on nine farms over a 2-year period showed the widespread presence of Phytophthora-related diseases in globe artichokes in the main producing area in Sardinia. Characteristic symptoms were represented by stunted growth, wilting and necrosis of basal leaves, dark brown discoloration of stem tissues, and crown and root rot. Furthermore, the plants eventually died (Figure 1). In addition, dark brown lesions with water-soaked halos were observed on bracts; the lesions often merged, affecting the entire capitula. Symptoms were more severe on inner bracts. 


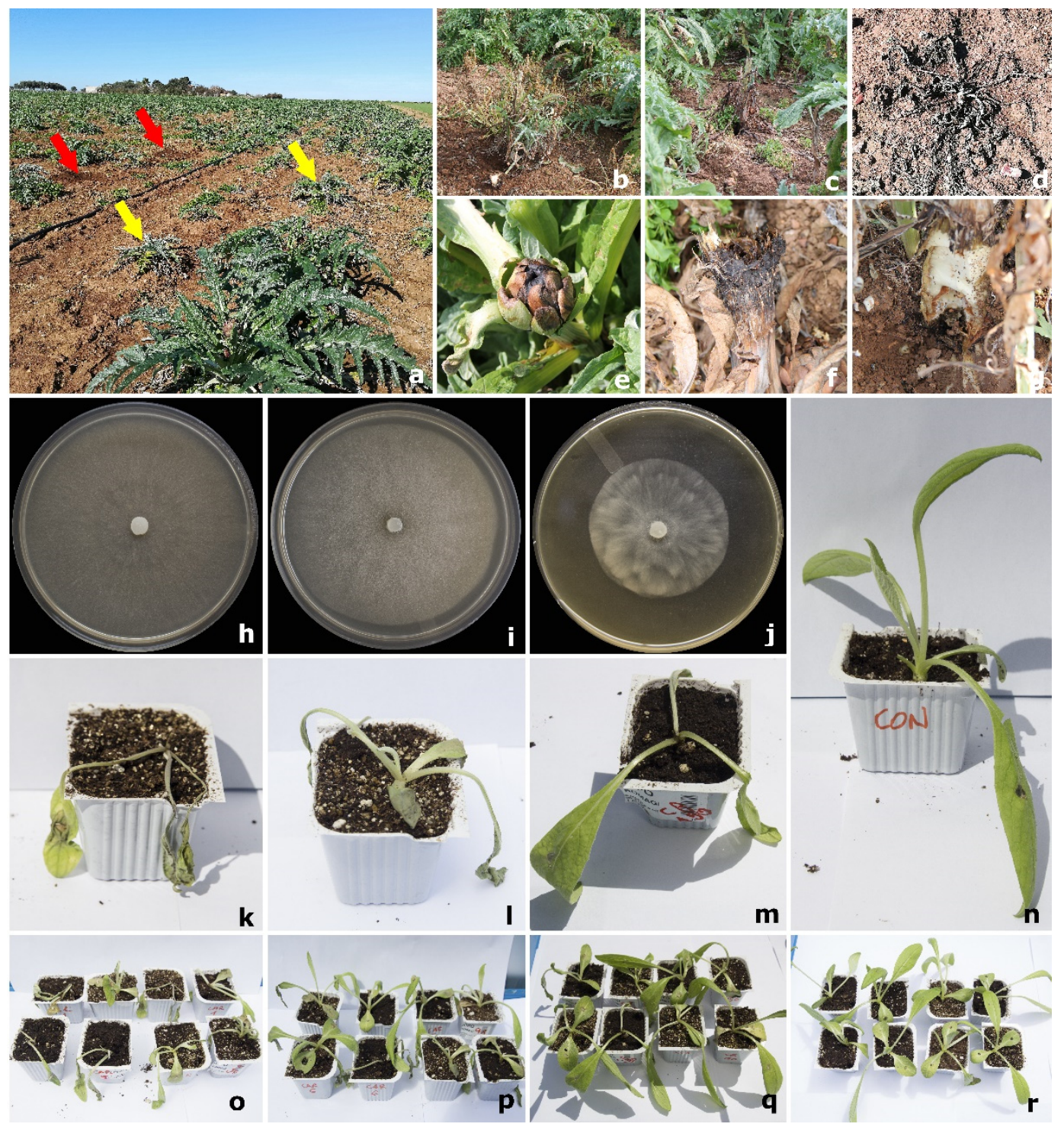

Figure 1. Overview of disease symptoms observed on globe artichokes: artichoke plantation severely impacted by the disease: red arrows indicate dead plants, whereas yellow arrows indicate plants with stunted growth and leaf symptoms (a); progressive wilting symptoms (b-d); dark brown lesions on bracts, basal stem and roots (e-g). Colony morphology of Phytophthora cactorum (h), P. crassamura (i), and P. marrasii (j) after 7 days growth at $25^{\circ} \mathrm{C}$ on CA in the dark. Symptoms observed on globe artichoke plants 5 days after inoculation with P. cactorum $(\mathbf{k}, \mathbf{o})$, P. crassamura $(\mathbf{1}, \mathbf{p})$, and P. marrasii (m,q). Control plants (n,r).

The 19 field-collected samples yielded a total of 18 Phytophthora colonies belonging to three species placed in three different clades. Based on morphological features, colony appearance, and ITS sequence data, Phytophthora isolates were identified as P. crassamura (eight isolates) and P. cactorum (4). In addition, six isolates, on the basis of morphological features and DNA sequence data, could not be assigned to any formally described species of Phytophthora and are therefore described here as Phytophthora marrasii sp. nov.

Phytophthora crassamura was the most common species detected in this study. Isolates were obtained from necrotic plant tissues and rhizosphere samples collected on six farms. Phytophthora cactorum was isolated from four samples (root and basal stem) collected on two farms, whereas the new Phytophthora species was obtained from symptomatic plant tissues on two farms. The plant mortality rates, especially in two-year-old plantations, were very high, with losses close to $30-40 \%$. In particular, farm F1 was the most impacted by the disease. 


\subsection{Phylogeny Clade 8}

Phylogenetic relationships among the described Phytophthora species belonging to clade 8 sensu Grünwald et al. [45] and the two isolates obtained in this study from artichokes were elucidated using ITS sequences. In addition, for species belonging to the subclade $8 c$, phylogenetic relationships were studied using concatenated ITS and Btub sequences, as well as ITS and cox 1 sequences. Fragments of approximately 800,920 , and $700 \mathrm{bp}$ were obtained for ITS, Btub, and cox1 regions, respectively.

The ML evolutionary reconstruction allowed for the differentiation of 21 distinct species within clade 8 (Figure 2).

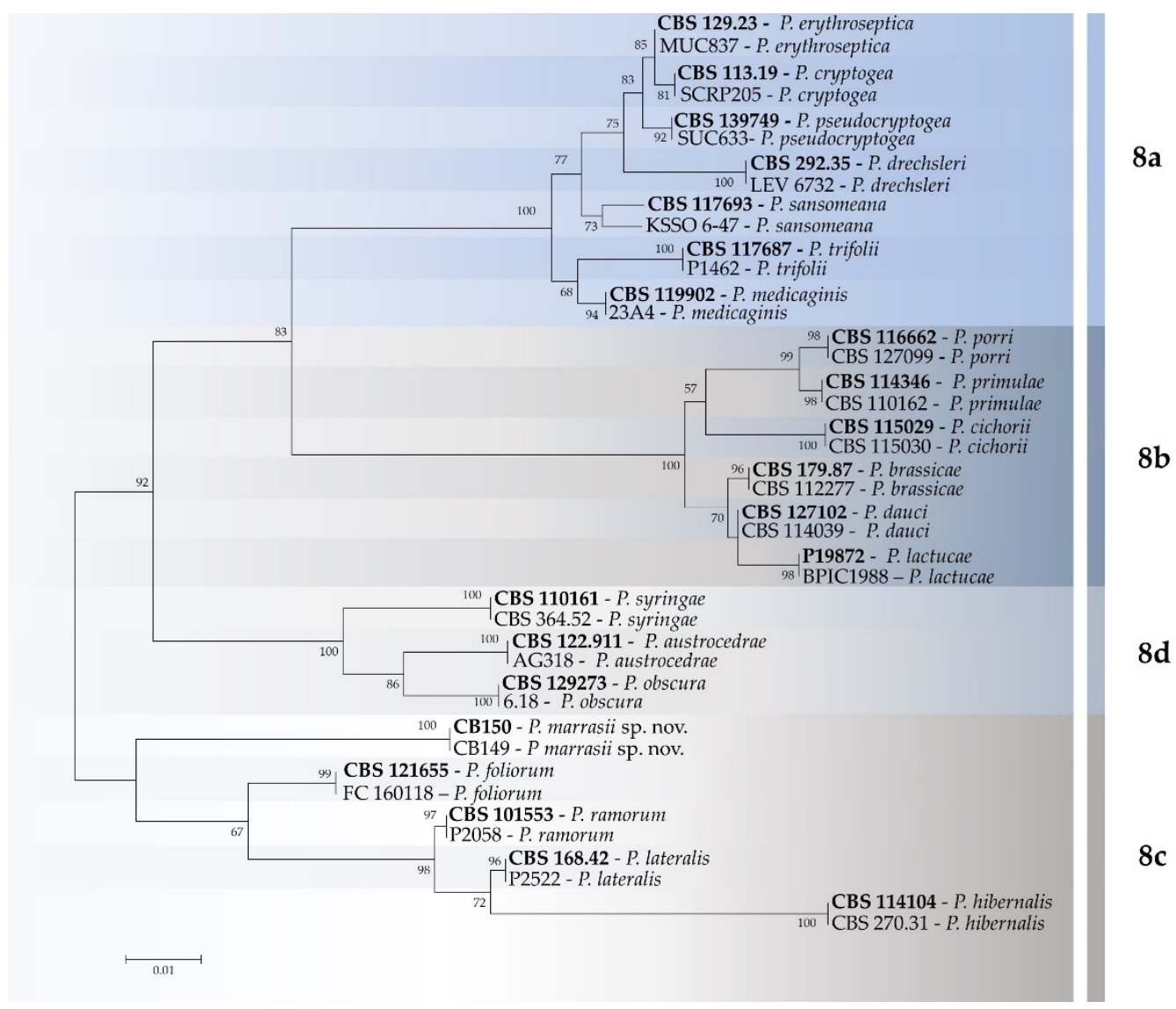

Figure 2. Maximum likelihood tree obtained from ITS sequences of Phytophthora species belonging to clade 8. Data are based on the General Time Reversible model. A discrete Gamma distribution was used to model evolutionary rate differences among sites. The tree is drawn to scale, with branch lengths measured in the number of substitutions per site. Bootstrap support values in percentage are given at the nodes. Ex-type cultures are in bold.

The monophyly of each of the previously recognized four subclades was generally well supported, and the two artichoke isolates clustered together in a well-supported terminal clade (ML bootstrap $=100 \%$ ) basal to sister species in the subclades 8c. Therefore, they were considered to represent a new species, described here as Phytophthora marrasii sp. nov.

Phylogenetic relationships of Phytophthora species belonging to subclade 8c based on the sequence data from concatenated ITS/Btub and ITS/cox1 regions were in accordance with that obtained with ITS sequences. Topology and branch lengths of maximum likelihood analysis are shown in Figures 3 and S1. Phylogenetically, the new Phytophthora species, is closely related to $P$. foliorum, from which it can be distinguished on the basis of 62,41 , and $49 \mathrm{bp}$ in ITS, Btub, and cox loci, respectively. The other evolutionarily closest species, P. ramorum, differs by a total of 153 nucleotides in the studied DNA regions. 


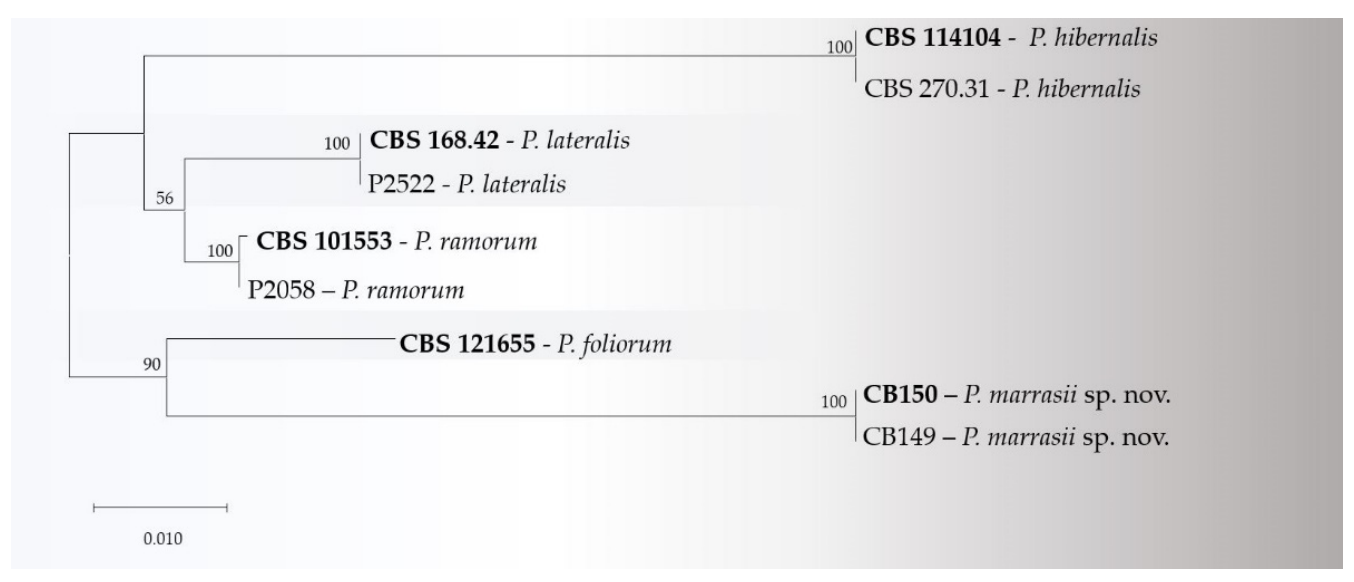

Figure 3. Maximum likelihood tree obtained from concatenated ITS and Btub sequences of Phytophthora species belonging to clade $8 \mathrm{c}$. Data are based on the general time reversible model. A discrete Gamma distribution was used to model evolutionary rate differences among sites. The tree is drawn to scale, with branch lengths measured in the number of substitutions per site. Bootstrap support values in percentages are given at the nodes. Ex-type cultures are in bold.

\subsection{Taxonomy}

Phytophthora marrasii Bregant, Rossetto, and Linaldeddu sp. nov. (Figure 4).

MycoBank: MB840582.

Etymology: in honour and memory of Professor Francesco Marras for his outstanding work on globe artichoke diseases.

Holotype: CBS H-24776.

Host/distribution: globe artichoke plants with crown and root rot symptoms in Sardinia (Italy).

Description: Sporangia were abundantly produced on CA plugs flooded in unsterile pond water after $36-72 \mathrm{~h}$ of incubation at $18{ }^{\circ} \mathrm{C}$ on simple sporangiophores. Morphology of sporangia: persistent, non-papillate, from ovoid to ellipsoid, less frequently elongated, sometimes with distorted shapes, constrictions, with a tapered base or a conspicuous basal plug (Figure 4). Sporangia average $74.2 \pm 19.2 \times 30.9 \pm 5.1 \mu \mathrm{m}$ (total range $47.8-132.6 \times$ $21.6-41.6 \mu \mathrm{m})$, with a length/breadth ratio of $2.4 \pm 0.2(n=50)$. Sporangial proliferation, usually external, sometimes internal, both nested and extended (Figure 4). Zoospores were abundantly produced in liquid cultures after $36-48 \mathrm{~h}$ at $18{ }^{\circ} \mathrm{C}$ (Figure 4 ). Hyphal swellings globose to subglobose, lobate, or irregular (Figure 4). Spherical chlamydospores principally terminal were rarely produced on CA (Figure 4). Chlamydospores average 24.9 $\pm 4.2 \mu \mathrm{m}$ (total range 17.4 to $31.1 \mu \mathrm{m}$ ). None of the $P$. marrasii isolates studied produced gametangia in single culture or when paired with other $P$. marrasii isolates or with A1 and A2 tester strains of P. cambivora, P. cinnamomi, P. citrophthora, and P. nicotianae on CA, whereas all isolates formed oogonia abundantly in single culture when flooded with non-sterile pond water. Smooth wall oogonia with an average of $30.7 \pm 3.1 \mu \mathrm{m}$ was principally terminal. Oospores spherical and usually aplerotic average $28.4 \pm 2.8 \mu \mathrm{m}$. Antheridia average $10.5 \pm 1.9 \times 9.1 \pm 1.5 \mu \mathrm{m}$ hyaline, rounded, club-shaped, or irregular mostly amphigynous (98\%), rarely paragynous $(2 \%)$.

Cultural characteristics: colony growth pattern cottony on PDA with an irregular border, stellate on MEA, and rosaceous to stellate on CA. On the PDA and MEA colony, growth was slow, whereas on the CA colony, growth reached a $62 \mathrm{~mm}$ diameter in 7 days at $23{ }^{\circ} \mathrm{C}$.

Cardinal temperatures for growth: minimum $<2{ }^{\circ} \mathrm{C}$, maximum $>28^{\circ} \mathrm{C}$, and optimum $23{ }^{\circ} \mathrm{C}$. Isolates failed to grow at $30^{\circ} \mathrm{C}$, and mycelium did not resume growth when plates were moved to $20^{\circ} \mathrm{C}$ (Figure S2). 

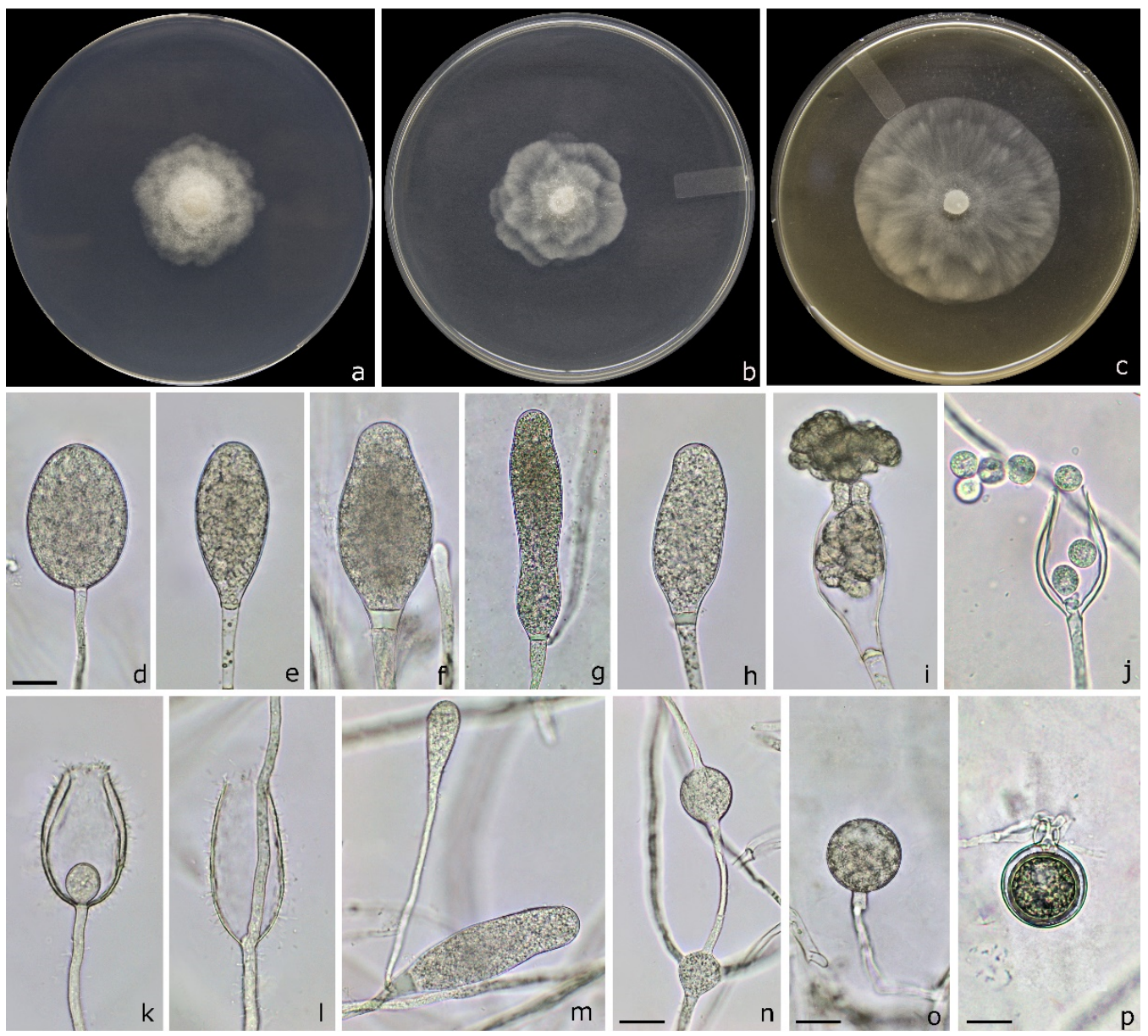

Figure 4. Colony morphology of Phytophthora marrasii (CB150) after 7 days growth at $25{ }^{\circ} \mathrm{C}$ on PDA (a), MEA (b), and CA (c). Non-papillate and persistent sporangia $(\mathbf{d}-\mathbf{h})$, release of zoospores $(\mathbf{i}, \mathbf{j})$, internal $(\mathbf{k}, \mathbf{l})$ and external $(\mathbf{m})$ proliferations, intercalary hyphal swellings (n), and a terminal chlamydospore (o). Oogonium with an amphygynous antheridium (p). Scale bars $=20 \mu \mathrm{m}$.

Material examined: ITALY: Samassi, isolated from a globe artichoke root, 17 February 2021, collected by B.T. Linaldeddu, isolated by Carlo Bregant, HOLOTYPE CBS H-24776, a dried culture on CA, culture ex-holotype CB150 = CBS 148033. ITALY: Samassi, isolated from rhizosphere and fine roots of a globe artichoke plant, 17 February 2021, collected by B.T. Linaldeddu, isolated by Carlo Bregant (isolate CB149).

Notes: Phytophthora marrasii differs from the closely related species $P$. foliorum and $P$. ramorum through a combination of unique morphological and molecular features, such as sporangia shape and sizes, cardinal temperature values, as well as a total of 152 (P. foliorum) and 153 (P. ramorum) fixed nucleotide differences in the ITS, Btub, and cox 1 sequences.

\subsection{Pathogenicity Tests}

All three Phytophthora species were shown to be pathogenic on globe artichokes. After 5 days, all plants inoculated with P. cactorum, P. crassamura, and P. marrasii displayed symptoms such as leaf chlorosis and collar and stem rot; the symptoms caused by P. cactorum were markedly more severe than those caused by other species (Table 3). Phytophthora cactorum rapidly colonized the entire plants, causing wilting symptoms and eventually death of the plants (Figure 1). Phytophthora crassamura and P. marrasii were shown to be less aggressive, although all the plants at the end of the test were symptomatic (Figure 1).

Control plants inoculated with sterile PDA plugs remained symptomless. All three Phytophthora species were successfully re-isolated from aerial tissues of all plants, thus fulfilling Koch's postulates. No Phytophthora colonies were isolated from control plants. 


\section{Discussion}

Diseases caused by Phytophthora species are reported in a wide range of economically important vegetable crops worldwide [46-48]. Despite the wide diffusion of globe artichoke cultivation in countries with a Mediterranean climate, little is known about the susceptibility of this winter-crop plant to the Phytophthora species.

Until now, studies on globe artichoke diseases have chiefly concerned the attacks of soil-borne fungal pathogens, such as A. rolfsii, $R$. solani, and Sclerotinia sclerotiorum agents of crown and root rot, wilting, and leaf chlorosis [23,25,27]. In addition, $V$. dahliae is reported as the main vascular pathogen worldwide [20,22]. Among the oomycetes, Pythium aphanidermatum is the only species reported as a root rot agent in California [49].

Investigations conducted in this study allowed us to expand knowledge about globe artichoke diseases and to detect severe attacks of Phytophthora spp. in the main globe artichoke producing area in Sardinia. In particular, diagnostic analysis allowed us to isolate and characterize three species of Phytophthora, which are reported here for the first time on globe artichokes. Inoculation experiments conducted on globe artichoke plants confirmed that all three Phytophthora species are pathogenic, supporting their direct involvement in the severe mortality that is currently threatening this herbaceous winter-crop in Sardinia. The species obtained are representative of three phylogenetic clades and included two previously known species: P. cactorum and P. crassamura, as well as a previous unknown species, described here as $P$. marrasii sp. nov.

Phytophthora marrasii was found to be associated with collar and root rot symptoms of globe artichoke plants. Phylogenetically, P. marrasii resides in clade 8, which currently encompasses 21 species, and is split into four subclades, which include species typical of both the agricultural and forestry fields $[48,50]$. The ITS phylogeny places $P$. marrasii in a terminal clade basal to the sister taxa (P. foliorum, P. hibernalis, P. lateralis, and P. ramorum) of clade 8c. In particular, $P$. marrasii is phylogenetically related to $P$. foliorum, a species from which it differs in 62,41 , and 49 nucleotides in the three DNA regions studied, respectively. At the same time, morphologically, P. marrasii can easily be distinguished from P. foliorum, mainly because of the low minimum temperature for growth, the bigger and persistent non-papillate sporangia, and smaller oogonia. None of the P. marrasii isolates obtained in this study produced gametangia in single or dual culture nor when paired with A1 and A2 tester isolates of different Phytophthora species. Isolates of Phytophthora species that appear sterile on suitable vegetable-based media, such as CA, may produce oogonia under specific external stimuli, suggesting a functioning but dormant breeding system $[37,46,51]$. This aspect has been observed for other species of Phytophthora [48,52].

Ecologically, P. marrasii is closer to the Phytophthora species of subclade $8 \mathrm{~b}$ because all of them are host-specific pathogens of herbaceous crops, whereas the sister species of subclade 8c (P. foliorum, P. hibernalis, P. lateralis, and P. ramorum) are typically associated with foliar blight, twig blight, and bleeding stem cankers on ornamentals and woody hosts in both timber plantations and natural ecosystems [48,53-55]. Interestingly, except P. marrasii, all clade $8 \mathrm{c}$ species known to date are characterized by caducous sporangia functional to aerial infections on leaves, twigs, and branches on ornamentals and trees [55-59].

In the present study, P. crassamura was the most frequent Phytophthora species isolated from the globe artichoke samples. Phytophthora crassamura was originally described in Sardinia from a Picea abies seedling and rhizosphere of Juniperus phoenicea [60] and more recently has been reported on several declining hosts in California, Australia, and Turkey [61,62]. Its reports have increased in the last years in both natural and semi-natural environments with a Mediterranean climate. A re-evaluation of ITS sequences deposited in GenBank as P. megasperma revealed that $P$. crassamura was previously recorded from different herbaceous plants, including Brassica napus and Solanum tuberosum in Australia (WPC P6820 and P7105) [60,63].

Phytophthora cactorum was the most aggressive species detected in this study. It is a widespread pathogen in natural environments and agriculture ecosystems in Europe, America, Asia, and Australia [64-66]. In the agriculture sector P. cactorum causes signif- 
icant economic losses in strawberry production worldwide $[67,68]$. Phylogenetically, $P$. cactorum falls within the phylogenetic clade 1, together with other Phytophthora species, such as P. infestans and P. phaseoli, notorious for the severe diseases caused to agricultural plants $[69,70]$.

All three Phytophthora taxa represent a new threat to globe artichoke production and need to be properly managed. This could be achieved through a combination of agronomic and phytosanitary practices, such as the selection of resistant varieties, adoption of proper irrigation practices, avoiding rotation with susceptible crops, and through the use of chemical treatments, although the oomycota fungicides currently available are very limited. The constant discovery of new Phytophthora diseases on crops [71-73] has exacerbated the problem of the correct management of these pathogens, emphasizing the need for new bioactive molecules [74].

\section{Conclusions}

Over the last decade, new Phytophthora species have continued to be discovered at an accelerated rate, especially in forest ecosystems and nurseries [75], whereas relatively few new species have been described from herbaceous crops [48]. The discovery of this new Phytophthora species emphasizes the importance of expanding the surveys on Phytophthora species associated with agricultural herbaceous crops to study disease potential, cycles of infection, survival strategies, and resistance to agrochemicals. In the specific case of P. marrasii, it will be interesting to evaluate the globe artichoke varietal resistance to this pathogen. Globe artichoke biodiversity in the Mediterranean area is vast, but the risk of genetic erosion posed by the limited number of vegetatively propagated varieties is high [76]. Sardinia harbours many artichoke varieties, representing an inestimable source of germplasm [77]; however, recently, to meet market needs and increase productivity, micro-propagated plants have been increasingly used [9]. The low temperature value for growth and a high production of sporangia in a temperature range between 12 and $18{ }^{\circ} \mathrm{C}$ suggest that $P$. marrasii is well adapted to infect winter crops and survive in the Mediterranean winter.

The origin of P. marrasii is not known. A survey is currently in progress to map the distribution of $P$. marrasii in Sardinia and to establish the natural and potential host range of this new taxon, as well as the possible threat posed to woody plants of the Mediterranean maquis.

Supplementary Materials: The following are available online at https:/ /www.mdpi.com/article/10 .3390/agriculture11090873/s1, Figure S1: maximum likelihood tree obtained from concatenated ITS and cox1 sequences of Phytophthora species belonging to clade 8c. Data are based on the General Time Reversible model. A discrete Gamma distribution was used to model evolutionary rate differences among sites. The tree is drawn to scale, with branch lengths measured in the number of substitutions per site. Bootstrap support values in percentage are given at the nodes. Ex-type cultures are in bold, Figure S2: mean colony diameter ( \pm standard deviation) of P. marrasii (isolates CB149 and CB150) after $96 \mathrm{~h}$ on $\mathrm{CA}$ in the dark at different temperatures.

Author Contributions: Conceptualization, B.T.L.; methodology, B.T.L., C.B., and L.M. (Lucio Montecchio); formal analysis, C.B., G.R., A.D., and L.M. (Lucia Maddau); investigation, B.T.L., A.F., and G.I.; data curation, B.T.L., A.R., and L.M. (Lucio Montecchio); writing-original draft preparation, B.T.L. and C.B.; writing-review and editing, C.B., G.R., A.D., L.M. (Lucia Maddau), A.F., G.I., L.M. (Lucio Montecchio), A.R., and B.T.L.; funding acquisition, B.T.L. All authors have read and agreed to the published version of the manuscript.

Funding: This research was funded by the project "Ricerca e sperimentazione di nuove strategie di lotta ecosostenibili contro le avversità parassitarie del carciofo". B.T.L. coordinator.

Institutional Review Board Statement: Not applicable.

Conflicts of Interest: The authors declare no conflict of interest. 


\section{References}

1. Mauro, R.; Portis, E.; Acquadro, A.; Lombardo, S.; Mauromicale, G.; Lanteri, S. Genetic diversity of globe artichoke landraces from Sicilian small-holdings: Implications for evolution and domestication of the species. Conserv. Genet. 2009, 10, 431-440. [CrossRef]

2. Calabrese, N.; Guyon, C.; Jana, C.; Martinez, J.P.; Minisini, S.; Vargas, S. From field to fork, three case studies to understand the globe artichoke supply chain. Acta Hort. 2020, 1284, 181-188. [CrossRef]

3. Basnizki, J.; Zohary, D. Breeding of seed-planted artichoke. Plant Breed Rev. 1994, 12, 253-269.

4. Colelli, G.; Calabrese, N. Il Carciofo e il Cardo; Bayer: Bologna, Italy, 2009.

5. Lattanzio, V.; Kroon, P.A.; Linsalata, V.; Cardinali, A. Globe artichoke: A functional food and source of nutraceutical ingredients. J. Funct. Food 2009, 1, 131-144. [CrossRef]

6. Ceccarelli, N.; Curadi, M.; Picciarelli, P.; Martelloni, L.; Sbrana, C.; Giovannetti, M. Globe artichoke as a functional food. Mediterr J. Nutr. Metab. 2010, 3, 197-201. [CrossRef]

7. Christaki, E.; Bonos, E.; Florou-Paneri, P. Nutritional and functional properties of Cynara crops (globe artichoke and cardoon) and their potential applications: A review. Int. J. Appl. Sci. Technol. 2012, 2, 64-70.

8. Zayed, A.; Serag, A.; Farag, M.A. Cynara cardunculus L.: Outgoing and potential trends of phytochemical, industrial, nutritive and medicinal merits. J. Funct. Foods 2020, 69, 103937. [CrossRef]

9. Cardarelli, M.; Rouphael, Y.; Saccardo, F.; Colla, G. An innovative vegetative propagation system for large-scale production of globe artichoke transplants. Part I. Propagation system setup. HortTechnology 2005, 15, 812-816. [CrossRef]

10. Pandino, G.; Barbagallo, R.N.; Lombardo, S.; Restuccia, C.; Muratore, G.; Licciardello, F.; Mazzaglia, A.; Ricceri, J.; Pesce, G.R.; Mauromicale, G. Quality traits of ready-to-use globe artichoke slices as affected by genotype, harvest time and storage time. Part I: Biochemical and physical aspects. LWT-Food Sci. Technol. 2017, 76, 181-189. [CrossRef]

11. Bravi, R.; Spataro, G.; Crino, P.; Saccardo, F. L'istituzione del Registro Varietale del carciofo. Seme 2008, 2, 24-29.

12. Mauro, R.P.; Lombardo, S.; Grazia Longo, A.M.; Pandino, G.; Mauromicale, G. New cropping designs of globe artichoke for industrial use. Ital. J. Agron. 2011, 6, 44-49.

13. Mauromicale, G.; Ierna, A. Panorama varietale e miglioramento genetico del carciofo. Inf. Agr. 2000, 56, 39-45.

14. Frau, A.; Mallica, G.; Baghino, L.; Cadinu, M.; Repetto, A. La micropropagazione del carciofo Spinoso sardo: Un valido mezzo per aumentare la produttività degli impianti. Italus Hortus 2004, 11, 38-41.

15. Rizzo, V.; Lombardo, S.; Pandino, G.; Barbagallo, R.N.; Mazzaglia, A.; Restuccia, C.; Mauromicale, G.; Muratore, G. Shelf-life study of ready-to-cook slices of globe artichoke 'Spinoso sardo': Effects of anti-browning solutions and edible coating enriched with Foeniculum vulgare essential oil. J. Sci. Food Agric. 2019, 99, 5219-5228. [CrossRef] [PubMed]

16. Bedini, L.; Lucchesini, M.; Bertozzi, F.; Graifenberg, A. Plant tissue cultures from four tuscan globe artichoke cultivars. Cent. Eur. J. Biol. 2012, 7, 680-689. [CrossRef]

17. Ozsan, T.; Onus, A.N. Callogenesis optimization of some globe artichoke [Cynara cardunculus var. scolymus (L.) Fiori] cultivars based on in vivo and in vitro leaf explants. Not. Bot. Horti Agrobo. 2020, 48, 1873-1884.

18. Ledda, L.; Mameli, M.G.; Milia, M.; Marras, G.F. Influence of plant shading and ovoli typology on globe artichoke development, early production and head atrophy: Preliminary results. Acta Hort. 2003, 660, 365-371. [CrossRef]

19. Bianco, V.V.; Calabrese, N. Problemi e prospettive della coltivazione, impiego e commercializzazione del carciofo. Atti del Workshop “Orticoltura di pien'aria in Italia: Quali prospettive per il comparto?". Sassari 2007, 16, 27-58.

20. Bhat, R.G.; Subbarao, K.V.; Bari, M.A. First Report of Verticillium dahliae causing artichoke wilt in California. Plant Dis. 1999, 83, 782. [CrossRef]

21. Armengol, J.; Berbegal, M.; Giménez-Jaime, A.; Romero, S.; Beltran, R.; Vicent, A.; Ortega, A.; García-Jiménez, J. Incidence of Verticillium wilt of artichoke in eastern Spain and role of inoculum sources on crop infection. Phytoparasitica 2005, 33, 397-405. [CrossRef]

22. Cirulli, M.; Bubici, G.; Amenduni, M.; Armengol, J.; Berbegal, M.; Jiménez-Gasco, M.; Jiménez-Díaz, R.M. Verticillium Wilt: A threat to artichoke production. Plant Dis. 2010, 94, 1176-1187. [CrossRef] [PubMed]

23. Marras, F. "I marciumi del colletto" del carciofo causati da Sclerotinia sclerotiorum (Lib.) Massee, dallo Sclerotium rolfsii Sac. e dalla Rhizoctonia solani Kuhn, in Sardegna. Studi Sass. Ann. Fac. Agr. Univ. Sassari 1962, 10, 90-103.

24. Marras, F.; Foddai, A.; Corda, P. La difesa del carciofo dalle malattie crittogamiche. Inf. Fitopatol. 1985, 9, 19-24.

25. Serra, S.; Maddau, L.; Franceschini, A.; Marras, F. Chemical and biological control of artichoke crown rot caused by Sclerotium rolfsii (Cynara scolymus L.). Italus Hortus 2004, 11, 74-77.

26. Larran, S.; Ronco, L.; Carranza, M.R.; Zuccaro, M. Grey mould of the globe artichoke in Argentina. Austral. Plant Pathol. 2008, 33, 461. [CrossRef]

27. Aydoğdu, M.; Kurbetli, İ.; Ozan, S. First report of Sclerotium rolfsii causing crown rot on globe artichoke in Turkey. Plant Dis. 2016, 100, 2161. [CrossRef]

28. Corda, P.; Fiori, M.; Carta, C. Osservazioni sul "marciume dei capolini" del carciofo (Cynara scolymus L.) da Botrytis cinerea Pers. in Sardegna. Studi Sass. Ann. Fac. Agr. Univ. Sassari 1982, 16, 193-197.

29. Ortega, A.; Perez, S. Aggressiveness of Verticillium dahliae isolates from potato to artichoke. Acta Hortic. 2007, 730, 407-412. [CrossRef]

30. Deligios, P.A.; Tiloca, M.T.; Sulas, L.; Buffa, M.; Caraffini, S.; Doro, L.; Sanna, G.; Spanu, E.; Spissu, E.; Urracci, G.R.; et al. Stable nutrient flows in sustainable and alternative cropping systems of globe artichoke. Agron. Sustain. Dev. 2017, 37, 54. [CrossRef] 
31. Penalver, R.; Duranvila, N.; Lopez, M.M. Characterization and pathogenicity of bacteria from shoot tips of the globe artichoke (Cynara scolymus L). Ann. Appl. Biol. 1994, 125, 501-513. [CrossRef]

32. Gallitelli, D.; Mascia, T.; Martelli, G.P. Viruses in artichoke. In Advances in Virus Research; Loebenstein, G., Lecoq, H., Eds.; Academic Press: Burlington, MA, USA, 2012; Volume 84, pp. 289-324.

33. Minutillo, S.A.; Spanò, R.; Gallitelli, D.; Mascia, T. Simultaneous detection of 10 viruses in globe artichoke by a synthetic oligonucleotide-based DNA polyprobe. Eur. J. Plant Pathol. 2021, 160, 991-997. [CrossRef]

34. Bregant, C.; Sanna, G.P.; Bottos, A.; Maddau, L.; Montecchio, L.; Linaldeddu, B.T. Diversity and pathogenicity of Phytophthora species associated with declining alder trees in Italy and description of Phytophthora alpina sp. nov. Forests 2020, 11, 848. [CrossRef]

35. Linaldeddu, B.T.; Mulas, A.A.; Bregant, C.; Piras, G.; Montecchio, L. First Report of Phytophthora pistaciae causing root and collar rot on nursery plants of Pistacia lentiscus in Italy. Plant Dis. 2020, 104, 1564. [CrossRef]

36. Bregant, C.; Mulas, A.A.; Rossetto, G.; Deidda, A.; Maddau, L.; Piras, G.; Linaldeddu, B.T. Phytophthora mediterranea sp. nov., a new species closely related to Phytophthora cinnamomi from nursery plants of Myrtus communis in Italy. Forests 2021, $12,682$. [CrossRef]

37. Brasier, C.M. Observations on the sexual mechanism in Phytophthora palmivora and related species. Trans. Brit. Mycol. Soc. 1972, 58, 236-251. [CrossRef]

38. Linaldeddu, B.T.; Maddau, L.; Franceschini, A.; Alves, A.; Phillips, A.J.L. Botryosphaeriaceae species associated with lentisk dieback in Italy and description of Diplodia insularis sp. nov. Mycosphere 2016, 7, 962-977. [CrossRef]

39. White, T.J.; Bruns, T.; Lee, S.; Taylor, J. Amplification and direct sequencing of fungal ribosomal RNA genes for phylogenetics. In PCR Protocols, a Guide to Methods and Applications; Innis, M.A., Gelfand, D.H., Sninsky, J.J., White, T.J., Eds.; Academic Press: San Diego, CA, USA, 1990; pp. 315-322.

40. Kroon, L.P.N.M.; Bakker, F.T.; Van Den Bosch, G.B.M.; Bonants, P.J.M.; Flier, W.G. Phylogenetic analysis of Phytophthora species based on mitochondrial and nuclear DNA sequences. Fungal Genet. Biol. 2004, 41, 766-782. [CrossRef] [PubMed]

41. Martin, F.N.; Tooley, P.W. Phylogenetic relationships among Phytophthora species inferred from sequence analysis of mitochondrially encoded cytochrome oxidase I and II genes. Mycologia 2003, 95, 269-284. [CrossRef]

42. Thompson, J.D.; Gibson, T.J.; Plewniak, F.; Jeanmougin, F.; Higgins, D.G. The CLUSTAL_X windows interface: Flexible strategies for multiple sequence alignment aided by quality analysis tools. Nucleic Acids Res. 1997, 25, 4876-4882. [CrossRef]

43. Hall, T.A. BioEdit: A user-friendly biological sequence alignment editor and analysis program for Windows 95/98/NT. Nucleic Acids Symp. Ser. 1999, 41, 95-98.

44. Kumar, S.; Stecher, G.; Li, M.; Knyaz, C.; Tamura, K. MEGA X: Molecular Evolutionary Genetics Analysis across computing platforms. Mol. Biol. Evol. 2018, 35, 1547-1549. [CrossRef] [PubMed]

45. Grünwald, N.; Werres, S.; Goss, E.M.; Taylor, C.R.; Fieland, V.J. Phytophthora obscura sp. nov., a new species of the novel Phytophthora subclade 8d. Plant Pathol. 2011, 61, 610-622. [CrossRef]

46. Erwin, D.C.; Ribeiro, O.K. Phytophthora Diseases Worldwide; American Phytopathological Society: St. Paul, MN, USA, 1996.

47. Granke, L.; Quesada-Ocampo, L.; Lamour, K.; Hausbeck, M. Advances in Research on Phytophthora capsici on Vegetable Crops in The United States. Plant Dis. 2012, 96, 1588-1600. [CrossRef]

48. Bertier, L.; Brouwer, H.; de Cock, A.W.; Cooke, D.E.; Olsson, C.H.; Höfte, M. The expansion of Phytophthora clade 8b: Three new species associated with winter grown vegetable crops. Persoonia 2013, 31, 63-76. [CrossRef]

49. Stanghellini, M.E.; Vilchez, M.; Kim, D.H.; Aguiar, J.L.; Armendariz, J. First report of root rot caused by Pythium aphanidermatum on artichoke. Plant Dis. 2000, 84, 811. [CrossRef] [PubMed]

50. Grünwald, N.J.; Garbelotto, M.; Goss, E.M.; Heungens, K.; Prospero, S. Emergence of the sudden oak death pathogen Phytophthora ramorum. Trends Microbiol. 2012, 20, 131-138. [CrossRef] [PubMed]

51. Brasier, C.M. Stimulation of sex organ formation in Phytophthora by antagonistic species of Trichoderma. I. The effect in vitro. New Phytol. 1975, 74, 183. [CrossRef]

52. Jung, T.; Stukely, M.J.; Hardy, G.E.; White, D.; Paap, T.; Dunstain, W.A.; Burgess, T.I. Multiple new Phytophthora species from ITS Clade 6 associated with natural ecosystems in Australia: Evolutionary and ecological implications. Persoonia 2011, 26, 13-39. [CrossRef] [PubMed]

53. Trionne, E.J.; Roth, L.F. Aerial infection of Chamaecyparis by Phytophthora lateralis. Plant Dis. Rep. 1957, 41, $211-215$.

54. Werres, S.; Marwitz, R.; In't veld, W.A.M.; De Cock, A.W.A.M.; Bonants, P.J.M.; De Weerdt, M.; Themann, K.; Ilieva, E.; Baayen, R.P. Phytophthora ramorum sp. nov., a new pathogen on Rhododendron and Viburnum. Mycol. Res. 2001, 10, 1155-1165. [CrossRef]

55. Donahoo, R.; Blomquist, C.L.; Thomas, S.L.; Moulton, J.K.; Cooke, D.E.; Lamour, K.H. Phytophthora foliorum sp. nov., a new species causing leaf blight of azalea. Mycol. Res. 2006, 110, 1309-1322. [CrossRef]

56. Rizzo, D.M.; Garbelotto, M.; Davidson, J.M.; Slaughter, G.W.; Koike, S.T. Phytophthora ramorum as the cause of extensive mortality of Quercus spp. and Lithocarpus densiflorus in California. Plant Dis. 2002, 86, 205-214. [CrossRef]

57. Blomquist, C.L.; Irving, T.; Osterbauer, N.; Reeser, P. Phytophthora hibernalis: A New pathogen on Rhododendron and evidence of cross amplification with two PCR detection assays for Phytophthora ramorum. Plant Health Prog. 2005, 6, 27. [CrossRef]

58. Brasier, C.M.; Vettraino, A.M.; Chang, T.T.; Vannini, A. Phytophthora lateralis discovered in an old growth Chamaecyparis forest in Taiwan. Plant Pathol. 2010, 59, 595-603. [CrossRef]

59. Brasier, C.M.; Webber, J. Sudden Larch Death. Nature 2010, 466, 824-825. [CrossRef] 
60. Scanu, B.; Linaldeddu, B.T.; Deidda, A.; Jung, T. Diversity of Phytophthora species from declining Mediterranean maquis vegetation, including two new species, Phytophthora crassamura and P. ornamentata sp. nov. PLoS ONE 2015, 10, e0143234. [CrossRef]

61. Lehtijärvi, A.; Kaya, A.G.A.; Woodward, S.; Jung, T.; Lehtijärvi, H.T.D. Oomycota species associated with deciduous and coniferous seedlings in forest tree nurseries of Western Turkey. For. Pathol. 2017, 47, e12363. [CrossRef]

62. Sims, L.L.; Chee, C.; Bourret, T.; Hunter, S.; Garbelotto, M. Genetic and phenotypic variation of Phytophthora crassamura isolates from California nurseries and restoration sites. Fungal Biol. 2019, 123, 159-169. [CrossRef]

63. Brasier, C.M.; Cooke, D.E.L.; Duncan, J.M.; Hansen, E.M. Multiple new phenotypic taxa from trees and riparian ecosystems in Phytophthora gonapodyides-P. megasperma ITS Clade 6, which tend to be high-temperature tolerant and either inbreeding or sterile. Mycol. Res. 2003, 107, 277-290. [CrossRef] [PubMed]

64. Benson, D.M.; Jones, R.K. Diseases of Woody Ornamentals and Trees in Nurseries; APS Press: St. Paul, MN, USA, 2001.

65. Pánek, M.; Fér, T.; Mrácek, J.; Tomsovský, M. Evolutionary relationships within the Phytophthora cactorum species complex in Europe. Fungal Biol. 2016, 120, 836-851. [CrossRef]

66. Burgess, T.I.; White, D.; McDougall, K.M.; Garnas, J.; Dunstan, W.A.; Català, S.; Carnegie, A.J.; Worboys, S.; Cahill, D.; Vettraino, A.M.; et al. Distribution and diversity of Phytophthora across Australia. Pac. Conserv. Biol. 2017, 23, 150-162. [CrossRef]

67. Ellis, M.A.; Madden, L.V. Leather Rot. Pages 33-35 in: Compendium of Strawberry Diseases, 2nd ed.; Maas, J.L., Ed.; The American Phytopathological Society: St. Paul, MN, USA, 1998.

68. Hantula, J.; Lilja, A.; Nuorteva, H.; Parikka, P.; Werres, S. Pathogenicity, morphology and genetic variation of Phytophthora cactorum from strawberry, apple, rhododendron, and silver birch. Mycol. Res. 2000, 104, 1062-1068. [CrossRef]

69. Grünwald, N.J.; Flier, W.G. The biology of Phytophthora infestans at its center of origin. Annu. Rev. Phytopathol. 2005, 43, 171-190. [CrossRef] [PubMed]

70. Evans, T.A.; Mulrooney, R.P.; Gregory, N.F.; Kee, E. Lima bean downy mildew: Impact, etiology, and management strategies for Delaware and the Mid-Atlantic Region U.S. Plant Dis. 2007, 91, 128-135. [CrossRef]

71. Linaldeddu, B.T.; Bregant, C.; Montecchio, L.; Favaron, F.; Sella, L. First report of Phytophthora acerina, P. pini and P. plurivora causing root rot and sudden death on olive trees in Italy. Plant Dis. 2020, 104, 996. [CrossRef]

72. Linaldeddu, B.T.; Bregant, C.; Ruzzon, B.; Montecchio, L. Coniella granati and Phytophthora palmivora the main pathogens involved in pomegranate dieback and mortality in north-eastern Italy. Ital. J. Mycol. 2020, 49, 92-100.

73. Decloquement, J.; Ramos-Sobrinho, R.; Elias, S.G.; Britto, D.S.; Puig, A.S.; Reis, A.; da Silva, R.A.F.; Honorato-Júnior, J.; Luz, E.D.M.N.; Pinho, D.B.; et al. Phytophthora theobromicola sp. nov.: A new species causing black pod disease on cacao in Brazil. Front. Microbiol. 2021, 12, 486. [CrossRef]

74. Lawrence, S.A.; Robinson, H.F.; Furkert, D.P.; Brimble, M.A.; Gerth, M.L. Screening a natural product-inspired library for anti-Phytophthora activities. Molecules 2021, 26, 1819. [CrossRef] [PubMed]

75. Scott, P.; Bader, M.K.F.; Burgess, T.I.; Hardy, G.; Williams, N. Global biogeography and invasion risk of the plant pathogen genus Phytophthora. Environ. Sci. Policy 2019, 101, 175-182. [CrossRef]

76. Portis, E.; Mauromicale, G.; Barchi, L.; Mauro, R.; Lanteri, S. Population structure and genetic variation in autochthonous globe artichoke germplasm from Sicily Island. Plant Sci. 2005, 168, 1591-1598. [CrossRef]

77. Cadinu, M.; Baghino, L.; Mallica, G.; Pisanu, A.B.; Repetto, A.; Tatti, A.M.; Muntoni, M. Collection of artichoke germplasm from different Mediterranean regions. Int. Symp. Artichoke Cardoon Wild Relat. 2011, 942, 103-108. [CrossRef] 